\title{
ANALISIS KINERJA KEUANGAN PERBANKAN SYARIAH (STUDI EMPIRIS BANK SYARIAH " BADAN USAHA MILIK NEGARA ", DI INDONESIA PERIODE 2015-2018)
}

\author{
Furqonti Ranidiah ${ }^{1}$ \\ E-mail : furqonti.ranidiah@gmail.com \\ Tezar Arianto ${ }^{2}$ \\ Email : Tezar.arianto7@gmail.com
}

\section{UNIVERSITAS MUHAMMADIYAH BENGKULU}

\begin{abstract}
This research is based on the importance of Islamic bank financial performance. Islamic bank financial performance is a picture of the achievements of banks in their operations, both related to the aspects of finance, marketing, collection and distribution of funds, technology, and human resources. This study aims to determine the financial performance of Islamic banking in Indonesia. Performance measurement tools that can be used based on financial statements is to calculate financial ratios so that they can find out the performance using ratio analysis. This research uses a quantitative approach to observe, gather information and present an analysis of research results. The population in this study is state-owned Islamic banks in Indonesia for the period 2015-2018. The sampling technique used was purposive sampling. The number of banks sampled were three Islamic banks. The analytical methods used in this study are Loan to Defosit Ratio (LDR), Capital Adequacy Ratio (CAR), Return on Assets (ROA), Return on Equity (ROE) and Operational Costs Against Operational Income (BOPO). The results of this study obtained the ratio of $L D R, C A R$ and BOPO in Islamic banking financial performance on average have good criteria. While the ROA and ROE ratio of Islamic banking has an average that is not good, for that ratio Return On Assets must be improved, especially in the aspect of managing assets to generate net profit. Likewise, the Return On Equity ratio can have the ability of equity in generating profits and utilizing owned capital capable of generating profits.
\end{abstract}

\section{Keywords: LDR, ROA, CAR, ROE dan BOPO}

\section{PENDAHULUAN}

Perusahaan perbankan di Indonesia akan membantu masyarakat dalam meningkatkan taraf hidupnya dan dapat membantu pemerintah dalam menyelesaikan masalah perekonomian yang terjadi pada negara akhir-akhir ini, karena suatu bank di suatu negara dapat dijadikan ukuran kemajuan negara yang bersangkutan. Semakin maju suatu negara, maka semakin besar peranan perbankan dalam mengendalikan negara tersebut. Artinya, keberadaan dunia perbankan semakin dibutuhkan pemerintah dan masyarakatnya. Sebagai salah satu lembaga keuangan, bank perlu menjaga kinerjanya agar dapat beroperasi secara optimal. Perekonomian tumbuh dan berkembang berbagai macam lembaga keuangan. Salah satu diantara lembaga-lembaga keuangan tersebut 
yang nampaknya paling besar peranannya dalam perekonomian adalah lembaga keuangan bank, yang lazimnya disebut bank (Martono, 2013:5). Bank merupakan lembaga keuangan yang menjadi tempat bagi perusahaan, badan-badan pemerintah dan swasta, maupun perorangan menyimpan dana-dananya. Melalui kegiatan perkreditan dan berbagai jasa yang diberikan, bank melayani kebutuhan pembiayaan serta melancarkan mekanisme sistem pembayaran bagi semua sektor perekonomian.

Bank merupakan lembaga perantara keuangan antara masyarakat yang kelebihan dana dengan masyarakat yang kekurangan dana (Kasmir, 2015:5). Masyarakat yang kelebihan dana menyimpan uangnya di bank kemudian bank menyalurkan dana itu kepada masyarakat yang membutuhkan dana. Hal ini merupakan tugas dari bank yang biasa disebut dengan intermediasi. Bank Syariah adalah Bank yang melaksanakan kegiatan usaha berdasarkan prinsip syariah, yang dalam kegiatannya memberikan jasa lalu lintas pembayaran, sedangkan Bank berdasarkan prinsip syariah yang beroperasi sesuai dengan prinsip-prinsip syariah islam, atau dengan kata lain yaitu bank yang tata cara beroperasinya mengacu kepada ketentuan-ketentuan Islam (Al-Quran dan Hadist). (UU No. 21 tahun 2008). Keuangan islam telah menyerang negara-negara dengan populasi Muslim minoritas seperti Inggris, Perancis dan Afrika Selatan. Lembagalembaga keuangan konvensional juga sangat ingin memperluas peraembehan jasa mereka telah merancang produk keuangan inovatif baru yang disalurkan kepada para pelanggan yang ingin melaksanakan transaksi keuangan berdasarkan kepercayaan agama mereka (Kevin et al., 2009).

Rabaa dan Younes (2016) dalam penelitiannya menyimpulkan bahwa di negara-negara CCG, perbankan syariah mengalami pertumbuhan pesat selama dua dekade terakhir. Ada banyak kontribusi faktor-faktor untuk pertumbuhan seperti itu, yang paling menonjol adalah liberalisasi keuangan. Larangan pembayaran bunga oleh Syariah Islam telah membuat ekuitas dan bagi hasil landasan kegiatan struktur operasionalnya. Selanjutnya, prinsip pembagian risiko memberikan alokasi dana jangka panjang yang lebih baik secara teoritis untuk investasi dengan profil pengembalian risiko yang lebih tinggi dan selanjutnya pertumbuhan ekonomi yang lebih besar. Dapat ditunjukkan bahwa efeknya positif dan signifikan pada pertumbuhan ekonomi selama periode 20012012 dalam hal keuangan liberalisasi.

Kinerja bank adalah salah satu faktor yang harus diperhatikan oleh bank untuk bisa terus bertahan hidup. Kinerja keuangan bank merupakan bagian dari kinerja bank secara keseluruhan, hal ini merupakan gambaran prestasi yang dicapai bank dalam operasionalnya, baik menyangkut aspek keuangan, pemasaran, penghimpunan dan penyaluran dana, teknologi, maupun sumber daya manusia. Alat ukur kinerja yang dapat digunakan dengan didasarkan pada laporan keuangan adalah dengan menghitung rasio-rasio keuangan sehingga dapat mengetahui kinerja tersebut dengan menggunakan analisis rasio. Hal mendasar yang membedakan antara lembaga keuangan konvensional dengan syariah adalah terletak pada pengembalian dan pembagian keuntungan yang diberikan oleh nasabah kepada lembaga keuangan dan/atau yang diberikan oleh lembaga keuangan kepada nasabah. Kegiatan operasional bank syariah menggunakan prinsip bagi hasil (profit and loss sharing). 
Bank Syariah yang dipilih dalam penelitian ini adalah Bank Umum Syariah yang telah go public. Bank Umum Syariah yang terdapat di Indonesia dan telah berdiri selama 3 tahun dan bank syariah merupakan anak perusahaan dari bank konvensional. Informasi yang digunakan untuk mengukur kinerja keuangan bank adalah berdasarkan laporan tahunan bank periode 2015-2018. Beberapa penelitian yang pernah dilakukan peneliti sebelumnya menemukan bahwa ada fakta untuk beberapa rasio kinerja keuangan, bank konvensional lebih baik dibandingkan dengan bank Syariah. Duwi Hardianti Muhammad Saifi (2018) dalam studi deskriptif kuantitatifnya pada bank umum konvensional dan bank umum syariah yang terdaftar dan diawasi oleh Otoritas Jasa Keuangan (OJK) menyimpulkan bahwa Bank Umum Konvensional memiliki kinerja keuangan yang lebih baik dibandingkan Bank Umum Syariah berdasarkan rasio LDR/FDR, ROA, ROE, BOPO dan NPL/NPF. Sedangkan Bank Umum Syariah memiliki kinerja keuangan yang lebih baik dibandingkan Bank Umum Konvensional berdasarkan rasio CAR.

Berdasarkan latar belakang di atas, maka peneliti tertarik untuk mengambil judul "Analisis Kinerja Keuangan Perbankan Syariah (Studi Empiris Bank Syariah "Badan Usaha Milik Negara" Di Indonesia Periode 2015-2018)".

\section{TINJAUAN PUSTAKA}

\section{Kinerja Keuangan Perbankan Syariah}

Kinerja keuangan menurut Suad dan Enny (2012:87) merupakan alat ukur kondisi keuangan dalam periode tertentu. Kinerja menunjukkan sesuatu yang berhubungan kekuatan serta kelemaha suatu perusahaan. Kekuatan yang dimiliki pun harus di pahami agar dapat di kembangkan dan di manfaatkan kemudian kelemahan juga harus di ketahui karena agar dapat melakukan perbaikan. Dalam menganalisa dan mengevaluasi suatu perusahaan dapat di awasi dari kondisi laporan keuangan perusahaan tersebut. Informasi dan posisi keuangan perusahaan sebelumnya sering kali menjadi perbandingan atau acuan memprediksi posisi keuangan dan kinerja masa depan. Kinerja merupakan hal penting yang harus di capai oleh setiap perusahaan di manapun, kinerja merupakan cerminan atau gambaran dari perusahaan tersebut dalam mengelola dan mengalokasikan sumberdaya yang di miliki.

Rasio merupakan alat ukur yang di gunakan dalam menganalisis laporan keuangan. Dengan menggunakan alat analisa beruapa rasio keuangan dapat menjelaskan dan memberikan gambaran kepada penganalisa tetang baik atau buruknya kondisi atau posisi keuangan suatu perusahaan per periode tertentu. Menurut Suad dan Enny (2012:72) analisis rasio keuangan adalah proses penentuan operasi yang penting dan karakteristik keuangan dari sebuah perusahaan dari data akuntnsi dan laporan keuangan. Tujuan dari analisis ini adalah untuk menentukan efisiensi kinerja dari perusahaan yang di wujudkan dalam catatan keuangan dan laporan keuangan. Dalam menggunakan analisis rasio keuangan pada dasarnya dapat melakukannya dengan perbandingan yaitu membandingkan rasio sekarang dengan rasio dari waktu yang telah lalu.

Menurut Suad dan Enny (2012:72- 73) rasio leverage yaitu rasio untuk mengukur seberapa jauh perusahan menggunakan hutang. Beberapa analisis menggunakan istilah 
rasio solvabilitas, yang berarti mengukur kemampuan perusahaan memenuhi kewjiban keuangannya. Beberapa rasio hutang yang di gunakan yaitu Dept To Equity Ratio, rasio ini menunjukkan perbandingan antara hutang dengan odal sendiri. Menurut Suad dan Enny (2012:74) rasio liquiditas rasio ini mengukur kemampuan perusahaan memenuhi kewajiban keuangan jangka pendek. Rasio-rasio yang dipergunakan adalah current ratio, rasio ini mengukur seberapa jauh aktiva lancar perusahaan dipakai untuk memenuhi kewajiban lancarnya. Quick Ratio, adalah sebuah rasio untuk mengukur kemampua perusahan daam menggunakan aktifa lancar untuk menutupi utang lancarnya.

Menurut Suad dan Enny (2012:75- 76) rasio profitabilitas, rasio ini digunakan untuk mengukur efisiensi penggunaan aktiva perusahaan (atau mungkin sekelompok aktiva perusahaan). Mungkin juga efisiensi ingin di kaitkan dengan penjualan yang berhasil di ciptakan. Sebagai misal ada jenis perusahaan yang mengambil keuntungan relatif yang cukup tinggi dari setiap penjualan (misal penjualan meubel, perhiasan, dan barang sebagainya), tetapi ada pula yang keuntungan relatifnya cukup rendah (seperti barangbarang keperluan seharihari). BEP (Basick Earnings Power), rasio ingin mengukur kemampuan aktiva perusahaan memperoleh laba dari operasi perusahaan. Karena hasil operasi yang di ukur, maka dipergunakan laba sebelum bunga dan pajak.

\section{Faktor-Faktor Yang Mempengaruhi Kinerja Keuangan Perbankan Syariah}

Faktor-faktor yang mempengaruhi suatu keputusan manajemen perusahaan perbankan adalah dengan melihat faktor internal dan faktor eksternal. Faktor internal dapat dikaitkan dengan pengambilan kebijakan dan strategi operasional bank seperti keputusan yang berkaitan dengan permodalan, pembiayaan serta pengelolaan risiko bank. Sementara faktor eksternal (faktor yang berasal dari luar perusahaan), meliputi kebijakan moneter, fluktuasi nilai tukar, dan tingkat inflasi, volatilitas tingkat bunga, dan inovasi instrumen keuangan. Analisa makro ekonomi merupakan analisis terhadap faktor-faktor eksternal yang bersifat makro, yang berupa peristiwa-peristiwa yang terjadi di luar perusahaan, sehingga tidak dapat dikendalikan secara langsung oleh perusahaan. Lingkungan ekonomi makro akan mempengaruhi operasional perusahaan yang dalam hal ini keputusan pengambilan kebijakan yang berkaitan dengan kinerja keuangan perbankan. Inflasi merupakan presentasi kecepatan kenaikan harga-harga dalam suatu tahun tertentu. Atau dengan kata lain adanya penurunan dari nilai mata uang yang berlaku. Secara teori inflasi berpengaruh terhadap dunia perbankan sebagai salah satu institusi keuangan. Sebagai lembaga yang fungsi utamanya sebagai mediasi, bank sangat rentan dengan resiko inflasi terkait dengan mobilitas dananya. Salah satu teori yang menjelaskan keterkaitan tersebut adalah teori dana yang dipinjamkan (theLoanable Fund Theory). Dalam teori ini apabila jumlah uang yang diminta melebihi jumlah yang disediakan, maka akan dapat mengakibatkan kenaikan harga uang atau tingkat suku bunga. 
Prinsip operasional bank syari'ah yang ditetapkan dalam penghimpunan dana masyarakat adalah dengan prinsip akad Wadi'ah dan Mudharabah, sesuai fungsi intermediary-nya maka bank berkewajiban untuk menyalurkan dana tersebut untuk pembiayaan. Pembiayaan merupakan fungsi bank dalam menjalankan fungsi penggunaan dana. Dari pembiayaan yang disalurkan, bank diharapkan dapat menghasilkan hasil, tingkat penghasilan dari pembiayaan merupakan tingkat penghasilan tertinggi bagi perbankan. Jadi semakin besar DPK yang berhasil dihimpun oleh bank syariah, maka semakin besar pula pembiayan yang disalurkan yang akhir bisa mempengaruhi positif terhadap ROA. Faktor selanjutnya adalah CAR yaitu rasio yang memperlihatkanseberapa besar jumlah seluruh aktiva bank yang mengandung risiko ikut dibiayai dari modal sendiri disamping memperoleh dana dari sumber diluar bank. Sehingga apabila rasio CAR semakin besar maka akan semakin baik Kinerja bank tersebut. Capital Adequacy Ratio (CAR) juga biasa disebut dengan rasio kecukupan modal, yangberarti jumlah modal sendiri yang diperlukan untuk menutup risiko kerugian yang timbul dari penanaman aktiva-aktiva yang mengandung risiko serta membiayai seluruh benda tetap dan investaris bank. Seluruh bank yang ada di Indonesia diwajibkan untuk menyediakan modal minimum sebesar $8 \%$ dari ATMR. Rasio BOPO merupakan rasio yang digunakan untuk mengukur kemampuan manajemen bank dalam mengendalikan biaya operasional terhadap pendapatan operasional. Semakin tinggi rasio ini maka akan semakin buruk kinerja bank tersebut karena bebaan operasional akan semakin tinggi.

\section{Indikator Kinerja Keuangan Perbankan Syariah}

\section{Loan to Deposit Ratio (LDR)}

Rasio LDR menyatakan seberapa jauh kemampuan bank dalam membayar kembali penarikan dana yang dilakukan deposan dengan mengandalkan kredit yang diberikan sebagai sumber likuiditasnya.

\section{Capital Adequacy Ratio (CAR)}

Capital Adequacy Ratio (CAR) merupakan rasio permodalan yang menunjukkan kemampuan bank dalam menyediakan dana untuk keperluan pengembangan usaha dan menampung risiko kerugian dana yang diakibatkan oleh kegiatan operasi bank.

\section{Return on Asset (ROA)}

Return on Asset (ROA) merupakan rasio yang menunjukkan hasil (return) atas jumlah aktiva yang digunakan dalam perusahaan.

\section{Return on Equity (ROE)}

Rasio ini menunjukkan efisiensi penggunaan modal sendiri. Semakin tinggi rasionya, maka semakin baik/kuat posisi pemilik perusahaan.

\section{Biaya Operasional terhadap Pendapatan Operasional (BOPO)}

Biaya Operasional Terhadap Pendapatan Operasional (BOPO) adalah perbandingan antara biaya operasional dengan pendapatan operasional dalam mengukur tingkat efisiensi dan kemampuan bank dalam melakukan kegiatan operasinya(BOPO) 


\section{METODE PENELITIAN}

\section{Tempat dan Waktu Penelitian}

Penelitian dilakukan pada Bank Syariah "BUMN" melalui situs resmi masing-masing Bank/web resmi idx.co.id.

\section{Jenis Penelitian}

Penelitian ini menggunakan pendekatan kuantitatif untuk mengamati,mengumpulkan informasi, dan menyajikan analisis hasil penelitian. Karena pada penelitian ini penulis menggunakan ilmu pengetahuan atau teori yang pernah diteliti oleh peneliti lain sehingga banyak memiliki acuan kepustakaan, variabel diketahui dan teori yang tersedia. Fakta atau realitas, objektif dan tunggal yang terpisah daripeneliti. Menurut Sugiyono (2013:23) pendekatan kuantitatif adalah pendekatan yangbersifat objektif, mencakup pengumpulan data dan analisis data kuantitatif sertamenggunakan metode pengujian statistik.

\section{Populasi dan Sampel \\ Populasi}

Populasi menurut Sugiyono (2013:34) adalah objek atau subjek yang mempunyai kualitas dan karakteristik tertentu yang ditetapkan oleh peneliti untuk mempelajari dan kemudian ditarik kesimpulannya. Populasi terdiri dari manusia atau orang, file atau dokumen yang dapat dipandang sebagai objek penelitian (Sugiyono, 2013:65). Populasi dalam penelitian ini adalah Bank Syariah BUMN Di Indonesia.

\section{Sampel}

Adapun teknik penentuan sampel dalam penelitian ini adalah dengan teknik purpossivesampling yaitu sampel diambil berdasarkan kriteria tertentu. Adapun kriterianya sebagai berikut :

1. Bank Syariah BUMN Di Indonesia

2. Bank yang menyajikan laporan keuangan selama 4 tahun berturut-turut yaitu dari 2015 sampai dengan 2018

Berdasarkan kriteria pemilihan sampel di atas, diperoleh jumlah sampel sebanyak tiga bank Syariah (PT. Bank BRI Syariah, PT Bank Mandiri Syariah, PT Bank BNI Syariah).

\section{Teknik dan Alat Pengumpulan Data}

Teknik Pengumpulan Data

Data yang dikumpulkan dalam penelitian ini dengan menggunakan metode dokumentasi, yaitu dengan cara mengumpulkan, mencatat, dan mengkaji data sekunder yang berupa laporan keuangan Bank Syariah BUMN Di Indonesia.Alat pengumpulan data dilakukan secara online pada website resmi masing-masing Bank Syariah.

\section{Metode Analisis}

\section{Rasio Likuiditas}

Loan to Deposit Ratio (LDR) 
Rasio LDR menyatakan seberapa jauh kemampuan bank dalam membayar kembali penarikan dana yang dilakukan deposan dengan mengandalkan kredit yang diberikan sebagai sumber likuiditasnya. Dengan kata lain, seberapa jauh pemberian kredit kepada nasabah dapat mengimbangi kewajiban bank untuk segera memenuhi permintaan deposan yang ingin menarik kembali uangnya yang telah digunakan oleh bank untuk memberikan kredit. Berdasarkan Martono (2013:84) perhitungan LDR sebagai berikut:

\section{Rasio Solvabilitas}

Capital Adequacy Ratio (CAR)

Capital Adequacy Ratio (CAR) merupakan rasio permodalan yang menunjukkan kemampuan bank dalam menyediakan dana untuk keperluan pengembangan usaha dan menampung risiko kerugian dana yang diakibatkan oleh kegiatan operasi bank. Menurut Martono (2013 : 88)Perhitungan CAR (Capital adequacy ratio) dirumuskan sebagai berikut:

$$
\text { CAR }=\frac{\text { Jumlah modal }}{\text { Jumlah ATMR (Aktiva Tertimbang Menurut Resiko) }}
$$

\section{Rasio Profitabiltas}

\section{Return on Asset (ROA)}

Return on Asset (ROA) merupakan rasio yang menunjukkan hasil (return) atas jumlah aktiva yang digunakan dalam perusahaan.

Rumus untuk mencari (ROA) adalah (Kasmir; 2011:202) :

$$
\mathrm{ROA}=\frac{\text { Laba setelah Pajak }}{\text { Total Aktiva }} \times 100 \%
$$

\section{Return on Equity (ROE)}

Rasio ini menunjukkan efisiensi penggunaan modal sendiri. Semakin tinggi rasionya, maka semakin baik/kuat posisi pemilik perusahaan.

Rumus untuk mencari Return on Equity (ROE) adalah (Kasmir; 2011:204) :

$$
\mathrm{ROE}=\frac{\text { Laba Setelah Pajak }}{\text { Total Equity }} \times 100 \%
$$

\section{Biaya Operasional terhadap Pendapatan Operasional (BOPO)}

Biaya Operasional Terhadap Pendapatan Operasional (BOPO) adalah perbandingan antara biaya operasional dengan pendapatan operasional dalam mengukur tingkat efisiensi dan kemampuan bank dalam melakukan kegiatan operasinya(BOPO) dirumuskan sebagai berikut:

$$
\text { BOPO }=\frac{\text { Total beban operasional }}{\text { Total Pendapatan Operasional }}
$$




\section{HASIL PENELITIAN DAN PEMBAHASAN}

\section{Hasil Analisis Kinerja Keuangan Perbankan Syariah}

\section{Loan to Deposit Ratio (LDR) Bank BRI Syariah}

Hasil perhitungan rasio LDR di Bank BRI Syariah, Bank BNI Syariah, dan Bank Mandiri Syariah selama periode 2015-2018 adalah sebagai berikut:

\section{Tabel 4.1}

Rasio LDR Bank BRI Syariah Periode 2015-2018

\begin{tabular}{|c|c|c|c|c|}
\hline No & Tahun & $\begin{array}{c}\text { Total Kredit } \\
(\mathbf{R p})\end{array}$ & $\begin{array}{c}\text { Dana Pihak Ketiga } \\
(\mathbf{R p})\end{array}$ & $\begin{array}{c}\text { LDR } \\
(\mathbf{\%})\end{array}$ \\
\hline 1 & 2015 & 16.660 .000 .000 .000 & 18.040 .000 .000 .000 & 84,78 \\
\hline 2 & 2016 & 18.040 .000 .000 .000 & 21.990 .000 .000 .000 & 82,04 \\
\hline 3 & 2017 & 19.010 .000 .000 .000 & 26.310 .000 .000 .000 & 72,25 \\
\hline 4 & 2018 & 26.310 .000 .000 .000 & 28.860 .000 .000 .000 .00 & 75,74 \\
\hline
\end{tabular}

Sumber: Data diolah 2019

Pada tahun 2015, rasio LDR pada Bank BRI Syariah adalah 84,74\%, dimana total kredit yang diberikan kepada nasabahnya secara Syariah adalah sebesar Rp.16.660.000.000.000,- dan dana pihak ketiga yang masuk adalah sebesar Rp.19.650.000.000.000,-. Pada tahun 2016, dana pihak ketiga yang masuk ke bank BRI Syariah adalah sebesar Rp.21.990.000.000.000,- sedangkan kredit yang diberikan kepada nasabahnya adalah sebesar Rp.18.040.000.000.000,- sehingga diperoleh rasio BOPO pada Bank BRI Syariah pada tahun 2016 adalah sebesar 82,04\%. Pada tahun 2017, rasio BOPO pada Bank BRI Syariah mengalami penurunan dibandingkan tahun sebelumnya yakni menjadi $72,25 \%$. Dana pihak ketiga yang masuk adalah Rp.26.310.000.000.000,- sedangkan total kredit yang diberikan adalah sebesar Rp.19.010.000.000.000,-. Pada tahun 2018, terjadi peningkatan rasio BOPO dibandingkan dengan tahun sebelumnya, yakni menjadi $75,74 \%$, dimana dana pihak ketiga sebesar Rp.28.860.000.000.000,- dan total kredit yang diberikan sebesar Rp.21.860.000.000.000,-.

\section{Rasio LDR Bank BNI Syariah}

Berikut ini adalah penjabaran perhitungan rasio LDR pada Bank BNI Syariah periode 2015-2018:

Tabel 4.2

Rasio LDR Bank BNI Syariah Periode 2015-2018

\begin{tabular}{|c|c|c|c|c|}
\hline No & Tahun & $\begin{array}{c}\text { Total Kredit } \\
(\mathbf{R p})\end{array}$ & $\begin{array}{c}\text { Dana Pihak Ketiga } \\
(\mathbf{R p})\end{array}$ & $\begin{array}{c}\text { LDR } \\
(\mathbf{\%})\end{array}$ \\
\hline 1 & 2015 & 17.765 .000 .000 .000 & 19.323 .000 .000 .000 & 91,94 \\
\hline 2 & 2016 & 20.494 .000 .000 .000 & 24.233 .000 .000 .000 & 84,57 \\
\hline 3 & 2017 & 25.597 .000 .000 .000 & 29.379 .290 .000 .000 & 87,13 \\
\hline 4 & 2018 & 28.299 .000 .000 .000 & 35.496 .520 .000 .000 & 79,72 \\
\hline
\end{tabular}

Sumber: Data diolah 2019

Pada tahun 2015, total kredit yang diberikan oleh Bank BNI Syariah adalah sebesar Rp.17.765.000.000.000,- sedangkan dana pihak ketiga yang dikelola oleh Bank BNI Syariah adalah sebesar Rp.19.323.000.000.000, sehingga diperoleh rasio LDR Bank 
BNI Syariah sebesar 91,94\%. Kemudian pada tahun 2016, Bank BNI Syariah memberikan kredit kepada nasabahnya sebanyak Rp.20.494.000.000.000,- sedangkan dana pihak ketiga yang dikelola adalah sebesar Rp.24.233.000.000.000,- sehingga diperoleh rasio LDR Bank BNI Syariah pada tahun 2016 adalah sebesar 84,57\%. Pada tahun 2017, rasio BOPO Bank BNI Syariah naik menjadi 87,13\%, dimana total kredit yang diberikan kepada nasabah adalah sebesar Rp.25.597.000.000.000,- sedangkan dana pihak ketiga yang dikelola adalah sebesar Rp.29.379.290.000.000,-. Dan pada tahun 2018, rasio LDR Bank BNI Syariah menurun menjadi 79,72\%, diperoleh dari total kredit sebesar Rp.28.299.000.000.000,- dan dana pihak ketiga yang dikelola sebesar Rp.35.496.520.000.000,-.

\section{Rasio LDR Bank Syariah Mandiri}

Berikut ini adalah penjabaran perhitungan rasio LDR pada Bank Syariah Mandiri periode 2015-2018:

Tabel 4.3

Rasio LDR Bank Syariah Mandiri Periode 2015-2018

\begin{tabular}{|c|c|c|c|c|}
\hline No & Tahun & $\begin{array}{c}\text { Total Kredit } \\
(\mathbf{R p})\end{array}$ & $\begin{array}{c}\text { Dana Pihak Ketiga } \\
(\mathbf{R p})\end{array}$ & $\begin{array}{c}\text { LDR } \\
(\boldsymbol{\%})\end{array}$ \\
\hline 1 & 2015 & 51.090 .000 .000 & 62.113 .000 .000 & 82,25 \\
\hline 2 & 2016 & 55.580 .000 .000 & 69.950 .000 .000 & 76,46 \\
\hline 3 & 2017 & 60.584 .000 .000 & 77.903 .000 .000 & 77,77 \\
\hline 4 & 2018 & 67.752 .797 .000 & 87.471 .843 .000 & 77,46 \\
\hline
\end{tabular}

Sumber: Data diolah 2019

Tahun 2015, rasio LDR pada Bank Syariah Mandiri adalah sebesar 82,25\% yang diperoleh dari total kredit sebesar Rp.51.090.000.000.000,- dan dana pihak ketiga yang dikelola sebesar Rp.62.113.000.000.000,-. Pada tahun 2016, rasio LDR pada Bank Syariah Mandiri adalah sebesar 79,46\%, kemudian terkoreksi menjadi 77,77\% di tahun 2017. Pada tahun 2018, terjadi peningkatan signifikan jumlah dana pihak ketiga yang masuk ke Bank Syariah Mandiri yaitu sebesar Rp.87.471.843.000.000,- sehingga diperoleh rasio LDR pada Bank Syariah Mandiri tahun 2018 sebesar 77,46\%.

\section{Capital Adequacy Ratio (CAR) Bank BRI Syariah}

Hasil perhitungan rasio CAR pada Bank BRI Syariah, Bank BNI Syariah, dan Bank Syariah Mandiri pada periode 2015-2018 adalah sebagai berikut:

\section{Tabel 4.4}

Rasio CAR Bank BRI Syariah Periode 2015-2018

\begin{tabular}{|c|c|c|c|c|}
\hline No & Tahun & $\begin{array}{c}\text { Jumlah Modal } \\
(\mathbf{R p})\end{array}$ & $\begin{array}{c}\text { Jumlah ATMR } \\
(\mathbf{R p})\end{array}$ & $\begin{array}{c}\text { CAR } \\
(\boldsymbol{\%})\end{array}$ \\
\hline 1 & 2015 & 2.343 .249 .000 .000 & 16.814 .444 .000 .000 & 13,94 \\
\hline 2 & 2016 & 3.467 .399 .000 .000 & 16.807 .175 .000 .000 & 20,63 \\
\hline 3 & 2017 & 3.611 .233 .000 .000 & 17.800 .175 .000 .000 & 20,29 \\
\hline 4 & 2018 & 5.922 .283 .000 .000 & 19.928 .066 .000 .000 & 29,72 \\
\hline
\end{tabular}

Sumber: Data diolah 2019 
Pada tahun 2015, jumlah modal yang di operasional oleh bank BRI Syariah adalah Rp.2.343.249.000.000,- sedangkan jumlah ATMR sebesar Rp. 16.814.444.000.000, sehingga diperoleh rasio CAR pada Bank BRI Syariah Tahun 2015 sebesar 13,94\%. Pada tahun 2016, terjadi peningkatan jumlah modal yang di operasional yakni menjadi Rp. 3.467.399.000.000, - sedangkan jumlah ATMR adalah sebesar Rp.16.807.175.000.000,- sehingga diperoleh rasio CAR Bank BRI Syariah tahun 2016 adalah sebesar 20,63\%. Pada tahun 2017, rasio CAR pada Bank BRI Syariah menurun menjadi 20,29\% dibandingkan dengan tahun sebelumnya. Pada tahun 2018, total modal yang di operasionalkan oleh Bank BRI Syariah meningkat signifikan menjadi Rp.5.992.283.000.000,- sedangkan jumlah ATMR adalah Rp.19.928.066.000.000,sehingga diperoleh rasio CAR bank BRI Syariah tahun 2018 sebesar 29,72\%.

\section{Rasio CAR Bank BNI Syariah}

Berikut ini adalah penjabaran perhitungan rasio CAR pada Bank BNI Syariah periode 2015-2018:

Tabel 4.5

Rasio CAR Bank BNI Syariah Periode 2015-2018

\begin{tabular}{|c|c|c|c|c|}
\hline No & Tahun & $\begin{array}{c}\text { Jumlah Modal } \\
\text { (Rp) }\end{array}$ & $\begin{array}{c}\text { Jumlah ATMR } \\
\text { (Rp) }\end{array}$ & $\begin{array}{c}\text { CAR } \\
(\boldsymbol{\%})\end{array}$ \\
\hline 1 & 2015 & 2.254 .181 .000 .000 & 12.414 .816 .000 .000 & 18,16 \\
\hline 2 & 2016 & 2.486 .600 .000 .000 & 16.666 .000 .000 .000 & 14,92 \\
\hline 3 & 2017 & 3.814 .100 .000 .000 & 18.939 .890 .000 .000 & 20,14 \\
\hline 4 & 2018 & 4.287 .820 .000 .000 & 22.207 .060 .000 .000 & 19,31 \\
\hline
\end{tabular}

Sumber: Data diolah 2019

Pada tahun 2015, jumlah modal yang dioperasional oleh Bank BNI Syariah adalah Rp. 2.254.181.000.000, - sedangkan jumlah ATMR sebesar Rp. 12.414.816.000.000, - sehingga diperoleh rasio CAR Bank BNI Syariah tahun 2015 seebsar $18,16 \%$.

Pada tahun 2016, jumlah modal yang dioperasional oleh Bank BNI Syariah adalah Rp.2.486.600.000.000,- sedangkan jumlah ATMR sebesar Rp Rp.16.666.000.000.000,sehingga diperoleh rasio CAR Bank BNI Syariah tahun 2016 sebesar 14,92\%. Pada tahun 2017, terjadi peningkatan jumlah modal yang dioperasional oleh Bank BNI Syariah yakni sebesar Rp.3.814.100.000.000,- sedangkan jumlah ATMR sebesar Rp.19.939.890.000.000,- sehingga diperoleh rasio CAR Bank BNI Syariah tahun 2017 sebesar 20,14\%. Pada tahun 2018, rasio CAR pada Bank BNI Syariah turun menjadi 19,31\% yang diperoleh dari jumlah modal sebesar Rp..4.287.820.000.000,- dan jumlah ATMR sebesar Rp.22.207.060.000.000,--

\section{Rasio CAR Bank Syariah Mandiri}

Berikut ini adalah penjabaran perhitungan rasio CAR pada Bank Syariah Mandiri periode 2015-2018: 
Tabel 4.6

Rasio CAR Bank Syariah Mandiri Periode 2015-2018

\begin{tabular}{|c|c|c|c|c|}
\hline No & Tahun & $\begin{array}{c}\text { Jumlah Modal } \\
(\mathbf{R p})\end{array}$ & $\begin{array}{c}\text { Jumlah ATMR } \\
(\mathbf{R p})\end{array}$ & $\begin{array}{c}\text { CAR } \\
(\mathbf{\%})\end{array}$ \\
\hline 1 & 2015 & 6.187 .390 .000 .000 & 48.146 .553 .000 .000 & 12,85 \\
\hline 2 & 2016 & 6.942 .002 .000 .000 & 49.555 .918 .000 .000 & 14,01 \\
\hline 3 & 2017 & 7.844 .125 .000 .000 & 49.350 .184 .000 .000 & 15,89 \\
\hline 4 & 2018 & 8.566 .771 .000 .000 & 52.670 .993 .000 .000 & 16,26 \\
\hline
\end{tabular}

Sumber: Data diolah 2019

Pada tahun 2015, jumlah modal yang dioperasional oleh Bank SyariahMandiri adalah Rp. 6.187.390.000.000, - sedangkan jumlah ATMR sebesar Rp.48.146.553.000.000,sehingga diperoleh rasio CAR Bank Syariah Mandiri tahun 2015 seebsar 12,85\%. Pada tahun 2016, jumlah modal yang dioperasional oleh Bank Syariah Mandiri adalah Rp.6.942.002.000.000,-Rp. 137.356.494.000.000,- sedangkan jumlah ATMR sebesar Rp.49.555.918.000.000,- sehingga diperoleh rasio CAR Bank Syariah Mandiri tahun 2016 sebesar 14,01\%. Pada tahun 2017, terjadi peningkatan jumlah modal yang dioperasional oleh Bank Syariah Mandiri yakni sebesar Rp.7.844.125.000.000,sedangkan jumlah ATMR sebesar Rp.49.350.184.000.000,- sehingga diperoleh rasio CAR Bank Syariah Mandiri tahun 2017 sebesar 15,89\%. Pada tahun 2018, modal yang dioperasional oleh Bank Syariah Mandiri kembali meningkat yakni sebesar Rp.8.566.771.000.000,- sedangkan jumlah ATMR sebesar Rp.52.670.993.000.000,sehingga diperoleh rasio CAR Bank Syariah Mandiri tahun 2018 sebesar 16,26\%.

\section{Rasio Profitabilitas}

Hasil perhitungan rasio ROA dan ROE pada Bank BRI Syariah, BNI Syariah, dan Syariah Mandiri dijabarkan sebagai berikut:

\section{Rasio ROA dan ROE Bank BRI Syariah}

Berikut ini adalah penjabaran perhitungan rasio ROA dan ROE pada Bank BRI Syariah periode 2015-2018:

\section{Tabel 4.7}

Rasio ROA dan ROE Bank BRI Syariah Periode 2015-2018

\begin{tabular}{|c|c|c|c|c|c|c|}
\hline $\begin{array}{l}\mathbf{N} \\
\mathbf{o}\end{array}$ & $\begin{array}{c}\text { Tahu } \\
\text { n }\end{array}$ & $\begin{array}{l}\text { Laba Bersih } \\
\text { (Rp) }\end{array}$ & $\begin{array}{l}\text { Total Aktiva } \\
\text { (Rp) }\end{array}$ & $\begin{array}{l}\text { Total Equitas } \\
\text { (Rp) }\end{array}$ & $\begin{array}{c}\text { RO } \\
\text { A } \\
(\%)\end{array}$ & $\begin{array}{c}\text { RO } \\
\text { E } \\
(\%)\end{array}$ \\
\hline 1 & 2015 & $\begin{array}{c}122.637 .000 .00 \\
0\end{array}$ & $\begin{array}{c}24.230 .247 .000 .0 \\
00\end{array}$ & $\begin{array}{c}2.339 .812 .000 .0 \\
00\end{array}$ & 0,51 & 5,24 \\
\hline 2 & 2016 & $\begin{array}{c}170.209 .000 .00 \\
0\end{array}$ & $\begin{array}{c}27.687 .188 .000 .0 \\
00\end{array}$ & $\begin{array}{c}2.510 .013 .000 .0 \\
00\end{array}$ & 0,61 & 6,78 \\
\hline 3 & 2017 & $\begin{array}{c}101.091 .000 .00 \\
0\end{array}$ & $\begin{array}{c}31.543 .384 .000 .0 \\
00\end{array}$ & $\begin{array}{c}2.602 .841 .000 .0 \\
00\end{array}$ & 0,32 & 3,88 \\
\hline 4 & 2018 & $\begin{array}{c}106.600 .000 .00 \\
0\end{array}$ & $\begin{array}{c}37.915 .084 .000 .0 \\
00\end{array}$ & $\begin{array}{c}5.026 .640 .000 .0 \\
00\end{array}$ & 0,28 & 2,12 \\
\hline
\end{tabular}

Sumber: Data diolah 2019

Pada tahun 2015, laba bersih yang diperoleh oleh Bank BRI Syariah adalah Rp.122.637.000.000,- sedangkan jumlah aktiva/asset yang dimilikinya sebesar 
Rp.24.230.247.000.000,- Rp.964.000.000.000.000,- sehingga diperoleh rasio ROA pada Bank BRI Syariah Tahun 2015 sebesar 0,51\%. Pada tahun 2016, laba bersih yang di peroleh Bank BRI Syariah adalah sebesar Rp.170.209.000.000, - sedangkan jumlah jumlah aktiva adalah sebesar Rp.27.687.188.000.000,- sehingga diperoleh rasio ROA Bank BRI Syariah tahun 2016 adalah sebesar 0,61\%. Pada tahun 2017, rasio ROA Bank BRI mengalami penurunan menjadi 0,32\%, dimana laba bersih yang diperoleh sebesar Rp.101.091.000.000,-dari asset sebesar Rp.31.543.384.000.000,-. Pada tahun 2018, Bank BRI Syariah mengalami pertumbuhan laba demikian juga dengan jumlah aset/aktiva. Namun rasio ROA pada Bank BRI Syariah pada tahun 2018 mengalami penurunan tipis menjadi 0,28\%. Pada tahun 2015, rasio ROE Bank BRI Syariah sebesar $5,24 \%$, kemudian mengalami pertumbuhan menjadi 6,78\% pada tahun 2016. Pada tahun 2017, Bank BRI Syariah membukukan laba bersih sebesar Rp.101.091.000.000,-dari jumlah ekuitas sebesar Rp.2.602.841.000.000,- sehingga diperoleh rasio ROE sebesar $3,88 \%$. Setahun berikutnya, rasio ROE Bank BRI Syariah mengalami penurunan menjadi $2,12 \%$, namun laba mengalami peningkatan signifikan yaitu menjadi Rp.106.600.000.000

\section{Rasio ROA dan ROE Bank BNI Syariah}

Berikut ini adalah penjabaran perhitungan rasio ROA dan ROE pada Bank BNI Syariah periode 2015-2018:

Tabel 4.8

Rasio ROA dan ROE Bank BNI Syariah Periode 2015-2018

\begin{tabular}{|c|c|c|c|c|c|c|}
\hline $\begin{array}{c}\text { N } \\
\mathbf{0}\end{array}$ & $\begin{array}{c}\text { Tahu } \\
\mathbf{n}\end{array}$ & $\begin{array}{c}\text { Laba Bersih } \\
(\mathbf{R p})\end{array}$ & $\begin{array}{c}\text { Total Aktiva } \\
(\mathbf{R p})\end{array}$ & $\begin{array}{c}\text { Total Equitas } \\
(\mathbf{R p})\end{array}$ & $\begin{array}{c}\text { RO } \\
\mathbf{A} \\
(\boldsymbol{\%})\end{array}$ & $\begin{array}{c}\text { RO } \\
\mathbf{E} \\
(\boldsymbol{\%})\end{array}$ \\
\hline 1 & 2015 & $\begin{array}{c}229.000 .000 .00 \\
0\end{array}$ & $\begin{array}{c}23.018 .000 .000 .0 \\
00\end{array}$ & $\begin{array}{c}2.216 .000 .000 .0 \\
00\end{array}$ & 0,99 & $\begin{array}{l}10,3 \\
3\end{array}$ \\
\hline 2 & 2016 & $\begin{array}{c}277.000 .000 .00 \\
0\end{array}$ & $\begin{array}{c}28.314 .175 .000 .0 \\
00\end{array}$ & $\begin{array}{c}2.486 .566 .000 .0 \\
00\end{array}$ & 0,98 & $\begin{array}{l}11,1 \\
4\end{array}$ \\
\hline 3 & 2017 & $\begin{array}{c}306.690 .000 .00 \\
0\end{array}$ & $\begin{array}{c}34.822 .440 .000 .0 \\
00\end{array}$ & $\begin{array}{c}3.807 .300 .000 .0 \\
00\end{array}$ & 0,88 & 8,06 \\
\hline 4 & 2018 & $\begin{array}{c}416.080 .000 .00 \\
0\end{array}$ & $\begin{array}{c}41.048 .540 .000 .0 \\
00\end{array}$ & $\begin{array}{c}4.242 .170 .000 .0 \\
00\end{array}$ & 1,01 & 9,81 \\
\hline
\end{tabular}

Sumber: Data diolah 2019

Pada tahun 2015, laba bersih yang diperoleh oleh Bank BNI Syariah adalah Rp.229.000.000.000, sedangkan jumlah aktiva/asset yang dimilikinya sebesar Rp. 23.018.000.000.000,- sehingga diperoleh rasio ROA pada Bank BNI Syariah Tahun 2015 sebesar 0,99\%. Pada tahun 2016, rasio ROA Bank BNI Syariah mengalami penurunan tipis yaitu menjadi $0,98 \%$. Hal ini terjadi seiring dengan pertumbuhan laba bersih menjadi Rp.277.000.000.000,-Rp.11.410.000.000.000,- dan jumlah asset sebesar Rp.28.314.175.000.000,- Pada tahun 2017, rasio ROA Bank BNI Syariah kembali mengalami penurunan menjadi $0,88 \%$, dimana laba bersih yang diperoleh sebesar Rp.306.690.000.000,- dari asset sebesar Rp.34.822.440.000.000,-. Pada tahun 2018, Bank BNI Syariah mengalami pertumbuhan rasio ROA yaitu menjadi $1,01 \%$. Laba yang dibukukan oleh Bank BNI Syariah mengalami pertumbuhan signifikan menjadi 
Rp.416.080.000.000,-. Demikian pula dengan jumlah asset yang dimilikinya mengalami pertumbuhan menjadi Rp.41.048.540.000.000,- Selama periode 2015-2018, rasio ROE Bank BNI Syariah mengalami fluktuatif. Pada tahun 2015, rasio ROE Bank BNI Syariah sebesar $10,33 \%$ dan meningkat menjadi $11,14 \%$ pada tahun 2016 . Pada tahun 2017, rasio ROE Bank BNI mengalami penurunan menjadi 8,06\% dan pada tahun 2018 tumbuh sedikit menjadi $9,81 \%$. Pada tahun 2018, terjadi pertumbuhan laba yang signifikan yakni menjadi Rp.416.080.000.000,- Hal ini berbanding lurus dengan jumlah ekuitas/modal yang di operasionalkan pada tahun 2018, yakni sebesar Rp. 4.242.170.000.000, - .

\section{Rasio ROA dan ROE Bank Syariah Mandiri}

Berikut ini adalah penjabaran perhitungan rasio ROA pada Bank Syariah Mandiri periode 2015-2018:

\section{Tabel 4.9}

Rasio ROA dan ROE Bank Syariah Mandiri Periode 2015-2018

\begin{tabular}{|c|c|c|c|c|c|c|}
\hline $\begin{array}{l}\mathbf{N} \\
\mathbf{o}\end{array}$ & $\begin{array}{c}\text { Tahu } \\
\text { n }\end{array}$ & $\begin{array}{l}\text { Laba Bersih } \\
\text { (Rp) }\end{array}$ & $\begin{array}{l}\text { Total Aktiva } \\
\text { (Rp) }\end{array}$ & $\begin{array}{l}\text { Total Equitas } \\
\text { (Rp) }\end{array}$ & $\begin{array}{c}\text { RO } \\
\text { A } \\
(\%)\end{array}$ & $\begin{array}{c}\text { RO } \\
\text { E } \\
(\%)\end{array}$ \\
\hline 1 & 2015 & $\begin{array}{c}289.576 .000 .00 \\
0\end{array}$ & $\begin{array}{c}70.369 .709 .000 .0 \\
00\end{array}$ & $\begin{array}{c}5.613 .739 .000 .0 \\
00\end{array}$ & 0,41 & 5,16 \\
\hline 2 & 2016 & $\begin{array}{c}325.414 .000 .00 \\
0\end{array}$ & $\begin{array}{c}\text { 78.369.709.000.0 } \\
00\end{array}$ & $\begin{array}{c}6.392 .437 .000 .0 \\
00\end{array}$ & 0,42 & 5,09 \\
\hline 3 & 2017 & $\begin{array}{c}365.166 .000 .00 \\
0\end{array}$ & $\begin{array}{c}87.915 .020 .000 .0 \\
00\end{array}$ & $\begin{array}{c}7.314 .241 .000 .0 \\
00\end{array}$ & 0,42 & 4,99 \\
\hline 4 & 2018 & $\begin{array}{c}605.212 .000 .00 \\
0\end{array}$ & $\begin{array}{c}98.341 .119 .000 .0 \\
00\end{array}$ & $\begin{array}{c}8.039 .165 .000 .0 \\
00\end{array}$ & 0,62 & 7,53 \\
\hline
\end{tabular}

Sumber: Data diolah 2019

Pada tahun 2015, Bank Syariah Mandiri membukukan laba bersih sebesar Rp. 289.576.000.000, - dari jumlah aktiva/asset yang dimilikinya sebesar Rp. 70.369.709.000.000, - sehingga diperoleh rasio ROA pada Bank Syariah Mandiri Tahun 2015 sebesar 0,41\%. Pada tahun 2016, rasio ROA pada Bank Syariah Mandiri mengalami pertumbuhan tipis dibandingkan tahun sebelumnya yakni menjadi $0,42 \%$. Hal ini terjadi seiring dengan peningkatan laba bersih yang diperoleh pada tahun 2016 yaitu sebesar Rp.325.414.000.000,- . Pada tahun 2017, rasio ROA Bank Syariah Mandiri sama dengan tahun sebelumnya yaitu $0,42 \%$. Namun demikian, terjadi pertumbuhan laba menjadi Rp.365.166..000.000,- dan pertumbuhan jumlah asset menjadi Rp. 87.915.020.000.000, - .

Pada tahun 2018, Bank Syariah Mandiri mengalami pertumbuhan laba bersih yang signifikan yakni menjadi Rp.605.212.000.000,- dari total asset sebesar Rp. 98.341.119.000.000, - sehingga rasio ROA Bank Syariah Mandiri tahun 2018 adalah 0,62\%. Selama periode 2015-2018, rasio ROE Bank Syariah Mandiri mengalami fluktuasi Pada tahun 2015, rasio ROE Bank Syariah Mandiri sebesar 5,16\% dan mengalami penurunan menjadi 5,09\% pada tahun 2016. Hal ini disebabkan oleh peningkatan jumlah ekuitas yang cukup signifikan pada tahun 2016 yaitu 
Rp. 6.392.437.000.000, - . Pada tahun 2017, rasio ROE Bank Mandiri kembali turun menjadi 4,99\% dan pada tahun 2018 tumbuh cukup signifikan menjadi 7,53\%.

\section{Rasio Biaya Operasional terhadap Pendapatan Operasional (BOPO)}

Berikut ini adalah penjabaran Rasio BOPO pada Bank BRI Syariah, Bank BNI Syariah dan Bank Syariah Mandiri selama periode 2015-2018.

\section{Rasio BOPO Bank BRI Syariah}

Berikut ini adalah penjabaran perhitungan rasio BOPO pada Bank BRI Syariah periode 2015-2018:

Tabel 4.10

Rasio BOPO Bank BRI Syariah Periode 2015-2018

\begin{tabular}{|c|c|c|c|c|}
\hline No & Tahun & $\begin{array}{c}\text { Total Beban } \\
\text { Operasional } \\
(\mathbf{R p})\end{array}$ & $\begin{array}{c}\text { Total Pendapatan } \\
\text { Operasional } \\
(\mathbf{R p})\end{array}$ & $\begin{array}{c}\text { BOPO } \\
(\mathbf{\%})\end{array}$ \\
\hline 1 & 2015 & 1.140 .000 .000 .000 & 2.420 .000 .000 .000 & 47,11 \\
\hline 2 & 2016 & 1.168 .424 .000 .000 & 1.726 .667 .000 .0000 & 67,67 \\
\hline 3 & 2017 & 1.178 .743 .000 .000 & 1.771 .609 .000 .000 & 66,54 \\
\hline 4 & 2018 & 1.200 .619 .000 .000 & 1.977 .389 .000 .000 & 60,72 \\
\hline
\end{tabular}

Pada tahun 2015, pendapatan dari kegiatan operasional Bank BRI Syariah adalah sebesar Rp.2.420.000.000.000,- sedangkan total beban operasional sebesar Rp.1.140.000.000.000,-sehingga rasio BOPO Bank BRI Syariah tahun 2015 adalah 47,11\%, cukup jauh di bawah batas toleransi. Pada tahun 2016, Bank BRI Syariah mengalami penurunan jumlah pendapatan operasional yakni menjadi sebesar Rp. 1.726.667.000.000, - sedangkan total beban operasional mengalami peningkatan menjadi Rp. 1.168.424.000.000, -- sehingga diperoleh rasio BOPO Bank BRI Syariah tahun 2016 sebesar 67,67\%. Pada tahun 2017, rasio BOPO Bank BRI Syariah mengalami penurunan menjadi $66,54 \%$, dimana pendapatan operasional yang diperoleh sebesar Rp.1.771.609.000.000, - sedangkan beban operasional sebesar Rp. 1.178.743.000.000, - . Pada tahun 2018, rasio BOPO Bank BRI Syariah mengalami penurunan menjadi $60,72 \%$. Hal ini terjadi karena pertumbuhan pendapatan operasional yang signifikan yaitu menjadi Rp. 1.977.389.000.000, - sedangkan beban operasional hanya sebesar Rp. 1.200.619.000.000, -

\section{Rasio BOPO Bank BNI Syariah}

Berikut ini adalah penjabaran perhitungan rasio BOPO pada Bank BNI Syariah periode 2015-2018:

Tabel 4.11

Rasio BOPO Bank BNI Syariah Periode 2015-2018

\begin{tabular}{|c|c|c|c|c|}
\hline No & Tahun & $\begin{array}{c}\text { Total Beban } \\
\text { Operasional } \\
(\mathbf{R p})\end{array}$ & $\begin{array}{c}\text { Total Pendapatan } \\
\text { Operasional } \\
(\mathbf{R p})\end{array}$ & $\begin{array}{c}\text { BOPO } \\
(\boldsymbol{\%})\end{array}$ \\
\hline 1 & 2015 & 1.340 .000 .000 .000 & 1.702 .000 .000 .000 & 78,73 \\
\hline 2 & 2016 & 1.606 .000 .000 .000 & 1.998 .000 .000 .000 & 80,38 \\
\hline 3 & 2017 & 1.914 .730 .000 .000 & 2.338 .000 .000 .000 & 81,90 \\
\hline 4 & 2018 & 2.150 .840 .000 .000 & 2.719 .000 .000 .000 & 79,10 \\
\hline
\end{tabular}

Sumber: Data diolah 2019 
Pada tahun 2015, pendapatan dari kegiatan operasional Bank BNI Syariah adalah sebesar Rp.1.340.000.000.000, - sedangkan total beban operasional sebesar Rp. 1.340.000.000.000, - sehingga rasio BOPO Bank BNI Syariah tahun 2015 adalah 78,73\%, masih di bawah batas toleransi. Pada tahun 2016, Bank BNI Syariah membukukan peningkatan jumlah pendapatan operasional yakni menjadi sebesar Rp. 1.998.000.000.000, - yang diikuti dengan peningkatan total beban operasional menjadi Rp. 1.606.000.000.000, - sehingga diperoleh rasio BOPO Bank BNI Syariah tahun 2016 sebesar 80,32\%. Pada tahun 2017, rasio BOPO Bank BNI Syariah meningkat menjadi $81,90 \%$, dimana pendapatan operasional yang diperoleh sebesar Rp. 2.338.000.000.000, - sedangkan beban operasional sebesar Rp. 1.914.730.000.000, - . Pada tahun 2018, rasio BOPO Bank BNI Syariah mengalami penurunan menjadi $79,10 \%$, dimana diperoleh pendapatan operasional sebesar Rp. 2.719.000.000.000, - sedangkan beban operasional hanya sebesar Rp. 2.150.840.000.000, - .

\section{Rasio BOPO Bank Syariah Mandiri}

Berikut ini adalah penjabaran perhitungan rasio BOPO pada Bank Syariah Mandiri periode 2015-2018:

Tabel 4.12

Rasio BOPO Bank Syariah Mandiri Periode 2015-2018

\begin{tabular}{|c|c|c|c|c|}
\hline No & Tahun & $\begin{array}{c}\text { Total Beban } \\
\text { Operasional } \\
(\mathbf{R p})\end{array}$ & $\begin{array}{c}\text { Total Pendapatan } \\
\text { Operasional } \\
(\mathbf{R p})\end{array}$ & $\begin{array}{c}\text { BOPO } \\
(\mathbf{\%})\end{array}$ \\
\hline 1 & 2015 & 4.090 .736 .000 .000 & 4.460 .651 .000 .000 & 91,71 \\
\hline 2 & 2016 & 4.545 .261 .000 .000 & 4.988 .248 .000 .000 & 91,12 \\
\hline 3 & 2017 & 5.218 .590 .000 .000 & 5.688 .796 .000 .000 & 91,73 \\
\hline 4 & 2018 & 5.315 .944 .000 .000 & 6.155 .934 .000 .000 & 86,35 \\
\hline
\end{tabular}

Sumber: Data diolah 2019

Pada tahun 2015, pendapatan dari kegiatan operasional Bank Syariah Mandiri adalah sebesar Rp.4.460.651.000.000, - sedangkan total beban operasional sebesar Rp. 4.090.736.000.000, - sehingga rasio BOPO Bank Syariah Mandiri tahun 2015 adalah 91,71\%, diatas toleransi 85\%. Pada tahun 2016, Bank Syariah Mandiri membukukan peningkatan jumlah pendapatan operasional yakni menjadi sebesar Rp. 4.998.248.000.000, - yang diikuti dengan peningkatan total beban operasional menjadi Rp. 4.545.261.000.000,-sehingga diperoleh rasio BOPO Bank Syariah Mandiri tahun 2016 sebesar 91,12\%.Pada tahun 2017, Bank Syariah Mandiri mengalami peningkatan rasio BOPO menjadi $91,73 \%$, dimana pendapatan operasional yang diperoleh sebesar Rp. 5.688.796.000.000, - sedangkan beban operasional sebesar Rp. 5.218.590.000.000,- . Pada tahun 2018, rasio BOPO Bank Syariah Mandiri mengalami perbaikan yaitu mengalami penurunan menjadi $86,35 \%$, dimana diperoleh pendapatan operasional sebesar Rp.6.155.934.000.000, - sedangkan beban operasional hanya sebesar Rp. 5.315.944.000.000, - 


\section{PEMBAHASAN}

\section{Rasio LDR}

Berdasarkan hasil penjebaran perhitungan rasio LDR, CAR, ROA, ROE, dan BOPO bank Syariah di atas dapat disusun tabel rangkuman hasil sebagai berikut:

\section{Tabel 4.2.1}

Rasio LDR Bank Syariah

\begin{tabular}{|l|c|c|c|c|c|c|}
\hline Bank Syariah & $\mathbf{2 0 1 5}$ & $\mathbf{2 0 1 6}$ & $\mathbf{2 0 1 7}$ & $\mathbf{2 0 1 8}$ & Rata-Rata & Kriteria \\
\hline BRI Syariah & 84,78 & 82,04 & 72,25 & 75,74 & 78,70 & Sehat \\
\hline BNI Syariah & 91,94 & 84,57 & 87,13 & 79,72 & 85,84 & Cukup Sehat \\
\hline $\begin{array}{l}\text { Mandiri } \\
\text { Syariah }\end{array}$ & 82,25 & 79,46 & 77,77 & 77,46 & 79,24 & Sehat \\
\hline Rata-Rata & 86,32 & 82,02 & 79,05 & 77,64 & 81,26 & Sehat \\
\hline
\end{tabular}

Sumber : Hasil Penelitian dan Data Diolah, 2019

Berdasarkan Tabel 4.2.1 nilai LDR Bank BRI Syariah adalah rasio LDR terendah, yaitu 78,70\% dan masuk pada kriteria sehat. Demikian pula dengan Bank Syariah Mandiri, berdasarkan rasio LDR nya, masuk pada kategori bank sehat. Dari ketiga bank Syariah, Bank BNI syariah memiliki nilai LDR yang paling tinggi, yaitu 85,84\% dan masuk pada kategori cukup sehat. Hal ini menggambarkan bahwa BNI syariah cukup mampu mengelola dana pihak ketiga untuk disalurkan kepada nasabah.

\section{Capital Adequacy Ratio (CAR)}

Aspek permodalan yang ada didasarkan kepada kewajiban penyediaan modal minimum bank dan penilaian tersebut salah satunya didasarkan kepada CAR (Capital Adequacy Ratio) yang telah ditetapkan BI. Bank Indonesia mewajibkan setiap bank umum menyediakan modal minimum CAR sebesar $8 \%$. Semakin tinggi rasio CAR suatu bank menunjukan bahwa bank tersebut semakin sehat serta kuat permodalannya. Nilai CAR untuk bank-bank syariah selama periode 2015-2018 dapat dilihat pada tabel 4.2.2 berikut ini:

Tabel 4.2.2

Rasio CAR Bank Syariah

\begin{tabular}{|c|c|c|c|c|c|c|}
\hline Bank Syariah & $\mathbf{2 0 1 5}$ & $\mathbf{2 0 1 6}$ & $\mathbf{2 0 1 7}$ & $\mathbf{2 0 1 8}$ & $\begin{array}{c}\text { Rata- } \\
\text { Rata }\end{array}$ & Kriteria \\
\hline BRI Syariah & 13,94 & 20,63 & 20,29 & 29,72 & 21,15 & Sangat Sehat \\
\hline BNI Syariah & 18,16 & 14,92 & 20,14 & 19,31 & 18,13 & Sangat Sehat \\
\hline Mandiri Syariah & 12,85 & 14,01 & 15,89 & 16,26 & 14,75 & Sangat Sehat \\
\hline Rata-Rata & 14,98 & 16,52 & 18,77 & 21,76 & 18,01 & Sangat Sehat \\
\hline
\end{tabular}

Sumber : Hasil Penelitian dan Data Diolah, 2019

Berdasarkan Tabel 4.2.2, dapat dilihat bahwa selama periode 2015-2018 Bank BRI Syariah merupakan bank Syariah yang memiliki rasio CAR tertinggi yaitu 21,15\% dan masuk pada kriteria sangat sehat. Di posisi kedua adalah Bank BNI Syariah yang memiliki rasio CAR sebesar 18,13\% dan masuk pada kriteria bank sangat sehat. Dan di posisi terendah adalah Bank Syariah Mandiri yang memiliki rasio CAR sebesar 14,75\%, namun masih masuk pada kriteria bank sangat sehat. 


\section{Return on Asset (ROA)}

Rasio ini digunakan untuk mengukur kemampuan manajemen bank dalam memperoleh keuntungan (laba) secara keseluruhan. Semakin besar ROA suatu bank, maka semakin besar pula tingkat keuntungan yang dicapai bank tersebut dan semakin baik pula posisi bank tersebut dari segi penggunaan asset. Standar ROA menurut Bank Indonesia adalah berkisar antara 0,5\%-1,25\% (Surat Edaran Bank Indonesia no.6/23/DPNP, 2004). Untuk bank syariah perkembangan tingkat ROA dari ketiga bank syariah untuk empat tahun berturut-turut dapat dilihat pada tabel berikut :

Tabel 4.2.3

Rasio ROA Bank Syariah

\begin{tabular}{|c|c|c|c|c|c|c|}
\hline Bank Syariah & $\mathbf{2 0 1 5}$ & $\mathbf{2 0 1 6}$ & $\mathbf{2 0 1 7}$ & $\mathbf{2 0 1 8}$ & $\begin{array}{c}\text { Rata- } \\
\text { Rata }\end{array}$ & Kriteria \\
\hline BRI Syariah & 0,51 & 0,61 & 0,32 & 0,28 & 0,43 & Kurang Sehat \\
\hline BNI Syariah & 0,99 & 0,98 & 0,88 & 1,01 & 0,97 & Cukup Sehat \\
\hline Mandiri Syariah & 0,41 & 0,42 & 0,42 & 0,62 & 0,47 & Kurang Sehat \\
\hline Rata-Rata & 0,64 & 0,67 & 0,54 & 0,64 & 0,62 & Cukup Sehat \\
\hline
\end{tabular}

Sumber : Hasil Penelitian dan Data Diolah, 2019

Berdasarkan Tabel 4.2.3, bank BNI Syariah merupakan bank syariah dengan rasio ROA yang paling tinggi yaitu $0,97 \%$ yang masuk pada kategori cukup sehat. Hal ini menggambarkan bahwa BNI syariah memiliki kemampuan yang tinggi dalam pencapaian laba karena untuk empat tahun terakhir BNI syariah mampu mencapai ROA dengan penilaian cukup sehat secara berturut-turut.

\section{Return on Equity (ROE)}

Tingkat pengembalian atas ekuitas (ROE) merupakan rasio untuk mengukur laba bersih sesudah pajak dengan modal sendiri. Rasio ini menunjukkan efisiensi penggunaan modal sendiri. Semakin tinggi rasionya, maka semakin baik/kuat posisi pemilik perusahaan. ROE untuk bank-bank syariah selama periode 2015-2018 dapat dilihat pada tabel berikut ini :

Tabel 4.2.4

Rasio ROE Bank Syariah

\begin{tabular}{|c|c|c|c|c|c|c|}
\hline Bank Syariah & $\mathbf{2 0 1 5}$ & $\mathbf{2 0 1 6}$ & $\mathbf{2 0 1 7}$ & $\mathbf{2 0 1 8}$ & $\begin{array}{c}\text { Rata- } \\
\text { Rata }\end{array}$ & Kriteria \\
\hline BRI Syariah & 5,24 & 6,78 & 3,88 & 2,12 & 4,51 & Kurang Sehat \\
\hline BNI Syariah & 10,33 & 11,14 & 8,06 & 9,81 & 9,84 & Cukup Sehat \\
\hline Mandiri Syariah & 5,16 & 5,09 & 4,99 & 7,53 & 5,69 & Cukup Sehat \\
\hline Rata-Rata & 6,91 & 7,67 & 5,64 & 6,49 & 6,68 & Cukup Sehat \\
\hline
\end{tabular}

Sumber : Hasil Penelitian dan Data Diolah, 2019

Pada Tabel 4.2.4 dapat dilihat bahwa selama periode 2015-2018, bank BNI Syariah merupakan bank syariah dengan rasio ROE yang terbaik, yaitu 9,84\% dan masuk pada ambang batas kategori bank cukup sehat. Sedangkan bank BRI Syariah, rasio ROE nya sedikit di bawah ambang batas 5\% sehingga masuk pada kategori bank kurang sehat. 
Penyebabnya adalah di tahun 2018, bank BRI Syariah tidak cukup efisien dalam menggunakan modal sendiri.

\section{Biaya Operasional terhadap Pendapatan Operasional (BOPO)}

Rasio ini digunakan untuk mengukur tingkat efisiensi dan kemampuan bank dalam melakukan kegiatan operasinya. Semakin rendah tingkat BOPO, maka semakin efisien tingkat biaya operasional yang dikeluarkan oleh bank tersebut. Biaya dan pendapatan operasional bank didominasi oleh biaya bunga dan pendapatan bunga mengingat tugas bank adalah sebagai penghimpun dan penyalur dana. Rasio BOPO yang baik dari standar Bank Indonesia adalah sekitar 94\%-96\%. BOPO pada bank syariah juga mengalami peningkatan dan penurunan untuk masing-masing bank. Adapun tingkat BOPO pada bank syariah seperti pada tabel 4.39.

Tabel 4.2.5

Rasio BOPO Bank Syariah

\begin{tabular}{|c|c|c|c|c|c|c|}
\hline Bank Syariah & $\mathbf{2 0 1 5}$ & $\mathbf{2 0 1 6}$ & $\mathbf{2 0 1 7}$ & $\mathbf{2 0 1 8}$ & $\begin{array}{c}\text { Rata- } \\
\text { Rata }\end{array}$ & Kriteria \\
\hline BRI Syariah & 47,11 & 67,67 & 66,54 & 60,72 & 60,51 & Sangat Sehat \\
\hline BNI Syariah & 78,73 & 80,38 & 81,90 & 79,10 & 80,03 & Sangat Sehat \\
\hline Mandiri Syariah & 91,71 & 91,12 & 91,73 & 86,35 & 90,23 & Sangat Sehat \\
\hline Rata-Rata & 72,52 & 79,72 & 80,06 & 75,39 & 76,92 & Sangat Sehat \\
\hline
\end{tabular}

Sumber : Hasil Penelitian dan Data Diolah, 2019

Pada Bank Syariah dapat dilihat bahwa penilaian BOPO untuk ketiga bank secara berturut-turut pada empat tahun terakhir memiliki penilaian sangat sehat. Karena bank bank mampu menghasilkan rasio BOPO yang berada di bawah ambang batas $94 \%$. Hal ini menggambarkan bahwa bank telah mampu mengecilkan semua biaya operasionalnya untuk meningkatkan pendapatan operasional.

\section{KESIMPULAN}

Berdasarkan hasil penelitian Analisis Kinerja Keuangan Bank Syariah maka dapat diambil kesimpulan bahwa:

1. Bank Syariah telah memenuhi standar LDR terbaik dari Bank Indonesia, Hasil di atas membuktikan bahwa kemampuan bank dalam menyediakan dana kepada debiturnya dengan modal yang dimiliki bank atau dana yang dikumpulkan dari masyarakat. Tingkat kemampuan Bank Syariah dalam memenuhi kewajibannya. Hal ini menunjukkan bahwa Bank Syariah mampu menyalurkan kreditnya dengan efektif sehingga jumlah kredit macetnya akan kecil, karena jumlah kredit yang disalurkan mempengaruhi keuntungan suatu bank.

2. Nilai CAR diperoleh Bank Syariah sebesar 18,01\%. Hasil di atas membuktikan bahwa Bank Syariah, belum mampu dalam menyediakan modal untuk memenuhi kegiatan bank secara efisien.

3. ROA diperoleh dengan Data ini menunjukkan bahwa kinerja keuangan Bank Syariah yang semakin baik, karena tingkat kembalian (return) semakin besar dan jika ROA perusahaan meningkat berarti profitabilitas perusahaan meningkat, sehingga dampak akhirnya adalah profitabilitas yang dinikmati oleh pemegang saham. Hasil di atas 
menunjukkan bahwa Bank Syariah dalam mengelola assetnya untuk menghasilkan laba bersih cukup baik.

4. Berdasarkan rasio ROE diperoleh Bank Syariah membuktikan bahwa Bank Syariah mempunyai kemampuan ekuitas dalam menghasilkan keuntungan baik dan memanfaatkan modal yang dimiliki mampu untuk menghasilkan laba.

5. Berdasarkan rasio BOPO diperoleh data menunjukkan bahwa tingkat efisiensi Bank Syariah lebih besar dalam menjalankan kegiatan usahanya. Karena Bank Syariah tidak memiliki kantor cabang yang lebih luas di Indonesia, selain itu Bank Syariah kurang memberikan pelayanan yang baik bagi nasabahnya dengan penyediaan fasilitas ATM yang tersedia dimana-mana.

\section{SARAN}

Berdasarkan kesimpulan maka penulis memberikan saran bahwa bank syariah untuk dapat meningkatkan kemampuannya dalam memperoleh laba baik dari segi ROA maupun dari ROE. Karena bank harus menunjukkan kemampuannya untuk mendapatkan laba dengan cara mengelola asset yang ada serta memanfaatkan modal yang ada.

\section{DAFTAR PUSTAKA}

Asma, Salman \& Huma Nawaz (2018), "Islamic finansial system and conventional bangking: A comparison”. Arab Economic abd Business Journal 155-167

Badri, Raba \&Bouljebene Younes (2016) "The Impact Of The Islamic Banks Performance On Economic Growth:Using Panel Data", International Journal Of Economics and Dinance Studies, Vol8,No 1, ISSN: 13098055(online)

Bank Indonesia. 1998. UU No. 10 tahun 1998, Tentang perubahan terhadap UU No. 7 tahun 1992, Jakarta.

Fahmi, Irham (2012) Analisis Kinerja Keuangan, Alfabeta, Bandung.

Kasmir. 2015. Bank dan Lembaga Keuangan Lainnya. Jakarta. PT Raja Grafindo Persada.

Kevin W, Gero V, Srilal M (2009). Investing with confidence: Understanding political risk management in the 21 century, 1 ed., World Bank publication, Washington DC.

Hamidah, Ramlan \& Mohd Sharrizat Adnan (2016), "The Profitability of Islamic and Conventional Bank: Case Study in Malaysa". Globsal journal of International Economics \& Business Management Conference.

Husnan, Suad., Enny Pudjiastuti, 2006. Dasar - dasar Manajemen Keuangan. UPP AMP YKPN. Yogyakarta. 
Martono, 2013, Bank dan Lembaga Keuangan Lainnya, Yogyakarta : Ekonisia Kampus Fakultas Ekonomi UII

Onakoya, Adegbemi Babatunde, (2013), "The Performance of Conventional and Islamic Banks in the United Kingdom : A Comparative Analysis". Journal of Research in Economics and International Finance (JREIF) (ISSN:23155671) Vol.2(2) pp 29-30

Riyadi, 2016. Analisis Kinerja Keuangan dan Perencanaan Keuangan Perusahaan. Jakarta: PT Gramedia Pustaka Utama.

Sugiyono, 2013. Metode Penelitian Kunatitatif Kualitatif dan R\&D. Cetakan Ke-18 . Bandung Alfabeta.

Undang-undang Republik Indonesia nomor 21 tahun 2008 Tentang Perbankan Syariah.

Wild, 2010. Analisis Laporan Keuangan, Buku. Satu, Edisi Sepuluh, Salemba Empat, Jakarta. 